\title{
Implementation of Communipreneur Concept In Development Campus Entreprenial
}

\author{
H. Muchsin al-Fikri ${ }^{1}$, Tresia Wulandari ${ }^{2}$, and Nur Aini Karimah ${ }^{3}$ \\ ${ }^{1,3}$ University of Sangga Buana, Kota Bandung, Jawa Barat, Indonesia \\ ${ }^{2}$ Universitas Pasundan, Kota Bandung, Jawa Barat, Indonesia \\ e-mail: muchsinalfikri2020@gmail.com
}

\begin{tabular}{|c|c|}
\hline Article Info & Abstract \\
\hline Article history: & This study aims to internalize the concept of communipreneur socialized by the Fac- \\
\hline Received & ulty of Social and Political Sciences, Sangga Buana University, Bandung and exam- \\
\hline April $12^{\text {th }}, 2021$ & ine the implementation of the communipreneur concept on the campus. Through \\
\hline Revised & a qualitative method approach, researchers conducted observations and dept-in- \\
\hline July $19^{\text {th }}, 2021$ & terviews with key informants namely the Vice Dean, Witri Cahyati, S. Sos, M.Si, \\
\hline Accepted & Chairperson of the Department of Communication Science, Pupi Indriati Zaelani, \\
\hline July $26^{\text {th }}, 2021$ & S. Sos, M. Si and several USB lecturers. This study produced several conclusions \\
\hline Published & including; Sangga Buana University as a campus that claims to be an entrepreneur \\
\hline \multirow[t]{5}{*}{ July $30^{\text {th }}, 2021$} & campus is required to make maximum efforts to apply the concept of entrepreneurs \\
\hline & to support the birth of students who are independent and entrepreneurial in the field \\
\hline & of Communication. The rector's policy was further broken down by the Communi- \\
\hline & cation Study Program at the Faculty of Social and Political Sciences by formulating \\
\hline & $\begin{array}{l}\text { and implementing the concept of communi-entrepreneur through four fields namely } \\
\text { photography, videography, public speaking and script writers. }\end{array}$ \\
\hline
\end{tabular}

Keywords: communipreneur; holistikpreneur; entrepreneurship

\begin{abstract}
Abstrak
Penelitian ini bertujuan untuk menginternalisasi konsep komunipreneur yang disosialisasikan oleh Fakultas Ilmu Sosial dan Politik Universitas Sangga Buana Bandung dan meneliti implementasi konsep komunipreneur di kampus tersebut. Melalui pendekatan metode kualitatif, peneliti melakukan observasi dan deptinterview kepada key informan yaitu Wakil Dekan, Witri Cahyati, S. Sos, M. Si, Ketua Jurusan Ilkom, Pupi Indriati Zaelani, S. Sos, M. Si dan beberapa dosen USB. Penelitian ini menghasilkan beberapa kesimpulan diantaranya; Universitas Sangga Buana sebagai kampus yang mengklaim sebagai kampus entrepreneur dituntut berupaya secara maksimal untuk menerapkan konsep enterpreneur guna mendukung terlahirnya para mahasiswa yang berjiwa mandiri dan berwirausaha di bidang Komunikasi. Kebijakan rektorat tersebut selanjutnya dibreakdown oleh Prodi Ilmu Komunikasi Fakultas Ilmu Sosial dan Politik (Fisip) dengan merumuskan dan mengimplementasikan konsep komunipreneur melalui empat bidang yaitu fotografi, videografi, publik speaking dan script wraiter.
\end{abstract}

Kata Kunci: komunipreneur; holistikpreneur; entrepreneurship 


\section{INTRODUCTION}

Entering the industrial era 4.0, the Indonesian nation and state were faced with challenges and threats of disruption in various fields, including communication. The dominance of robotic systems, artificial intelligence and the internet in all fields inevitably has eliminated a number of professions that have resulted in an increase in the number of intellectual unemployment in the country.

Even high schools now no longer guarantee the ease of getting a job. Educated unemployment is actually increasing. Low school graduates quickly find jobs. Job opportunities for educated people are expanding, but many are unable to meet job requirements.

The Central Statistics Agency (BPS) reported employment conditions in Indonesia during February 2017 to February 2018. Based on data submitted by BPS, the open unemployment rate (TPT) of university graduates increased by 1.13 percent compared to February 2017. From 5.18 percent to 6, 31 percent.
That was said by the Head of the Central Statistics Agency (BPS), Suhariyanto who said unemployment from diploma graduates I / II / III also rose by 1.04 percent from 6.88 percent to 7.92 percent. An increase in unemployment also occurred at the elementary school level. The unemployment rate rose 0.05 percent from 2.62 percent to 2.67 percent. However, compared to other levels of education, unemployment from elementary school graduates is the least. "Those with low education tend to be willing to accept any kind of work, it can be seen from the lowest elementary school TPT among all levels of education, which is 2.67 percent," Suhariyanto said at the Jakarta BPS Kantro on Monday (7/5/2018). Despite an increase in unemployment among university, diploma and elementary school graduates, according to BPS data, overall the unemployment rate in Indonesia has decreased. Compared to 2017, the number of employed people increased by 2.53 million while unemployment decreased by 140 thousand.

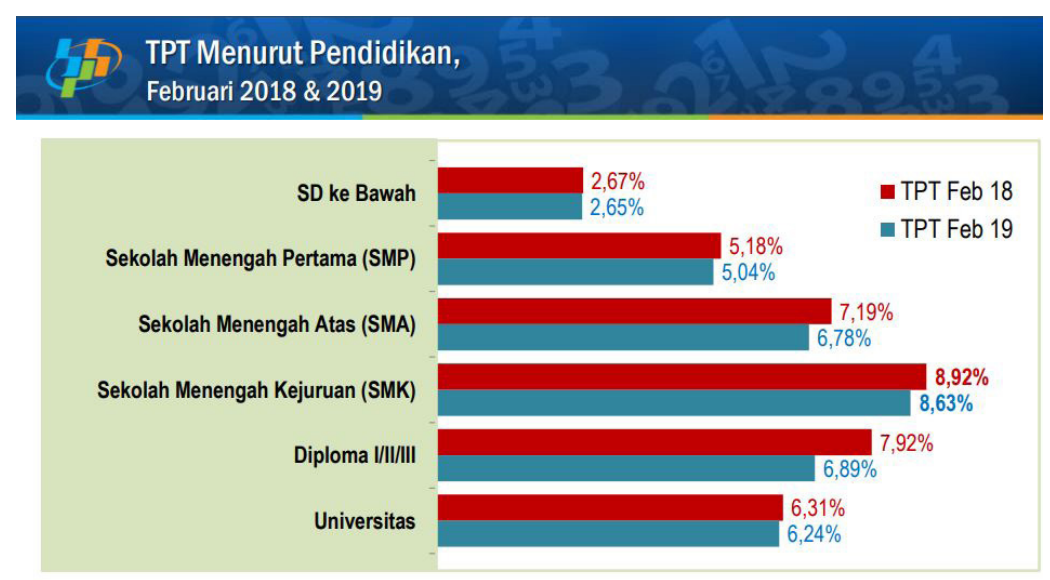

Figure 1. The open unemployment rate (TPT) of university graduates Source : Badan Pusat Statistik

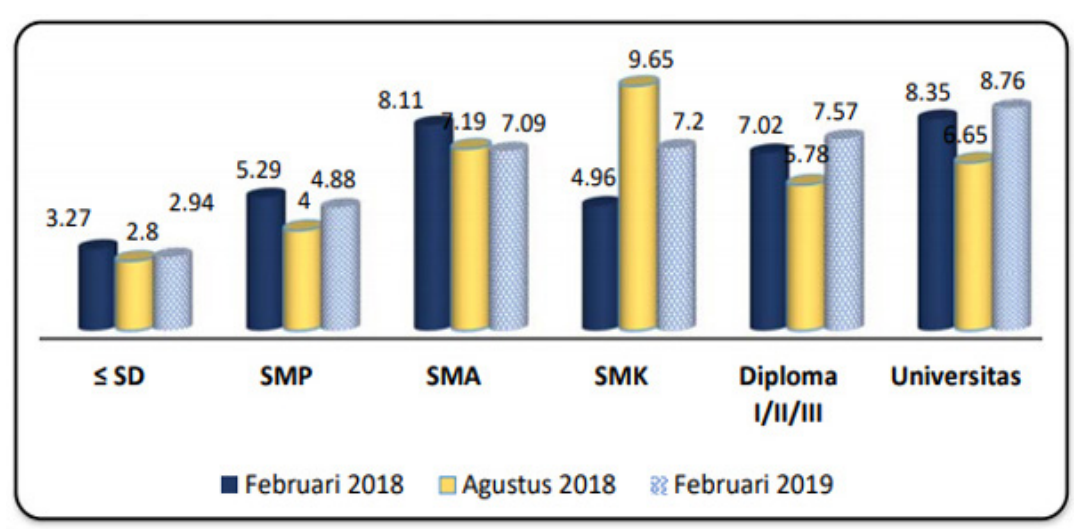

Figure 2. Unemployment among university, diploma and elementary school graduates Source : Badan Pusat Statistik 
The problem with the large number of unemployment experienced today by University alumni in Indonesia is not only experienced by our country. It is said that in the past 1980 to 1996 the United States had also been hit by educated unemployment which was expanding in the midst of unfavorable economic and socio-political conditions. In the midst of very complex conditions there is one of the Universities in America namely MIT (Massachusetts Institute of Technology) which has a breakthrough of genius that is changing the mindset of the entire academic community by changing the direction of its Higher Education policy from the High Learning Institute and Reseach University to Entrepreneurial University.

Although initially there were many pros and cons to the policy, over a period of 16 years, MIT was able to prove the birth of four thousand companies from the hands of its alumni by absorbing 1.1 million workers and a turnover of 232 billion dollars per year. It's a very spectacular achievement that changed the condition of America into a super power country. In America until now more than 12 percent of the population has become entrepreneurs, every 11 seconds new entrepreneurs are born and data shows that 1 in 12 Americans are directly involved in entrepreneurial activities. Japan also does not want to lose, 10 percent of its population as entrepreneurs and more than 240 Japanese companies of small, medium and large scale entrenched in our country. As a result, Japan was born to become the richest country in Asia. Likewise, in our neighboring countries, Singapore and Malaysia, the fact is that more than 7.2 percent of Singaporean entrepreneurs and more than 3 percent of Malaysian entrepreneurs have made the growth of various fields, especially economic growth, farther away. While our country only has 0.8 percent of entrepreneurs, aka less than 1 percent of the current population.

In fact, to develop the nation's economy, to become a developed nation, according to Sociologist David McCleiland, at least 2 percent of entrepreneurs are needed from the population, or about 4.8 million entrepreneurs in Indonesia today.

Reflecting on the success of developed countries such as America, Japan, Singapore and Malaysia, almost all universities in Indonesia including Sangga Buana University (USB) Bandung try to insert entrepreneurship material at least in two semesters and insert entrepreneurship material into all subjects. Even through the Chancellor's policy delivered at the
2019 Work Meeting USB began to change the vision and mission and mindset of the academic community to become an entrepreneur campus. Previously, the Business Incubator institution and the directorate of entrepreneurship were also formed as a form of USB's seriousness in realizing the entrepreneurship campus.

In addition to being an entrepreneur campus, the Chancellor also has an obsession with USB so that he can apply the holisticpreneur concept. The word holistic comes from English which means that the emphasis is on the importance of the whole and the relationship between each of the parts that make it up. Holisticpreneur is a perspective or business life perspective that never separates between Catholics (Creator), the universe, humans and society. All of them are elements of life that are complementary and coherent and complement each other and live in balance. It is expected by the Chancellor that students in building a business are not only for profit purposes, but also involve the community, respecting environmental principles, ethics and other human values. So the purpose of the communipreneur is the development of aspects of tawazun or balance between the world and the hereafter. All students are directed to be able to develop the three potential they have, namely physical, intellectual and spiritual.

The Faculty of Social and Political Sciences (FISIP) USB through the Communication Department seeks to capture that spirit by reconstructing the Communipreneur concept and implementing it in the form of coaching and training for vocational / high school students and students. Through community service activities, the lecturers and Communication Science students traveled to several vocational / high schools to spread the 'virus' of the communicators.

\section{METHOD}

This study uses a qualitative descriptive approach by exploring primary data available on campus as well as secondary data in the form of interviews or dept-interviews with several informants including the Director of Business Incubators and the Director of Entrepreneurship. Based on the level of study, it is exploratory research. The type of data collected is mostly in the form of qualitative data and the nature of the analysis used, so the qualitative research approach is more appropriate. Data collection techniques with interviews, observation and documentation techniques. Heri Kuswara, observer and activist of Entrepreneurship. 


\section{RESULTS AND DISCUSSION}

As if competing, almost all tertiary institutions, both public and private, are now introducing entrepreneurship education on their campuses. All of them flock to cultivate the value of entrepreneurship on campus. They realize that to produce graduates with reliable entrepreneurial spirit will ultimately improve the nation's economy.

Efforts and efforts to instill the spirit and spirit of entrepreneurship to students in the USB campus environment continue to be encouraged by the Rector. According to the USB Chancellor, to realize Sangga Buana as an entrepreneur campus, at least six strategic steps have been implemented, namely;

\section{Establishment of Business Incubator Institutions \& Entrepreneurship Directorate}

An incubator based on KBBI, means tools that are heated with electricity and so on are used to incubate and incubate eggs, or to heat babies born prematurely. Thus if it is associated with a business or starup that is currently busy using the term business incubator, it means that the incubator is a place where the starup business is maturing itself to produce something.

Meanwhile, according to the National Business Incubator Association (NBIA), that Business incubator is a business support process that can accelerate the successful development of startups and startup companies by providing various resources and services needed to entrepreneurs. These services are usually developed or managed by the incubator management and are offered both within the business incubator itself and through the network owned by the business incubator.

USB Business Incubator or abbreviated as IBIS USB was established in 2015 by cooperating with many tenants from MSMEs. IBIS experienced ups and downs and experienced several changes. In 2018 it was separated from the directorate of entrepreneurship, but has now been put back together.

Through this institution a lot of activities have been carried out such as Entrepreneurship Seminars, talk shows, short courses, Workshops, Workshops, business practices, business cooperation, entrepreneurship Expo, Entrepreneurship Challange etc. All of these activities involve students as targets for the spread of this entrepreneurship virus. Even alumni who have successfully taken part in various business fields are invited to share their experiences in the field of entrepreneurship.

\section{Increasing Workforce competence and productivity for students}

The tight war of competence in the digital era forced the campus to equip its students with various types of competencies even according to the new $\mathrm{PP}$ each campus was required to issue a Companion Certificate for its students. Students are forced to plan their careers as early as possible. During this time there are still many students who rely on the greatness of the name of their alma mater compared to their personal competence. Whereas the majority of companies look more at the applicant's personal competence than the origin of his alma mater.

Realizing the importance of competency aspects for prospective workers and students, USB continues to hold competency enhancement training for prospective workforce and increase productivity for students.

\section{Provision of venture capital for Start Up students}

Strarup business is a start-up business that was built from scratch, which means that there are really many new companies that don't have branches or use franchise methods and so on. Many tips are needed to set up a star up and get initial capital in order to build a business that is solid, stable and also lasts for a long time to be distributed or passed on to future children and grandchildren. If you use your own capital to build a business, of course it will not be enough because the costs required are very expensive and large, so the campus needs to open access to capital to students.

In addition to providing training to students, the USB campus also seeks to provide access to capital for students who become Start-ups in the business field. Either by cooperating with the banking world or the business world by optimizing the distribution of corporate CSR.

\section{Arrange the Curriculum}

Professor of the Faculty of Economics, UI, Rhenald Kasali stated that currently entrepreneurship has become a subject in various universities. He proposed that universities place entrepreneurship as an honorable subject in their respective campuses. In fact lectures should be done 90 percent of practice and 10 percent are theory.

To produce graduates with entrepreneurial spirit and insight, USB seriously designs entrepreneurship courses / materials for students ranging from curriculum making, syllabus, Teaching Event Unit (SAP), presentation slides, theory modules, practice modules / practice, manuals making etc. The campus 
must also form a team that is truly expert and experienced in various fields of science and must involve non-economic academics and practitioners / business people as well as entrepreneurship motivators so that the material provided is weighted. This is important because the collaboration between academics, practitioners and motivators will produce entrepreneurial concepts and ideas that are appropriate and appropriate for students from various scientific disciplines. The choice can be compacted in entrepreneurship courses or included in all courses.

\section{Increased HR Lecturer entrepreneurship}

To foster its students, USB recruits inspirational and motivational people who are able to convey material well and interestingly. Even lecturers who have a business are preferred, so they can share their stories with their students.

In addition, the USB campus has also tried to prepare lecturers who are capable of " $5 \mathrm{M}$ " as follows: (1) able to provide a new paradigm about the importance of entrepreneurship. (2) able to change / direct student mindset into an entrepreneurial spirit. (3) able to inspire and motivate students to become independent HR. (4) able to provide examples of real entrepreneurial work (goods / services) and present success stories. (5) able to produce human resources students / alumni become an intra-preneur or successful entrepreneur.

In addition, the lecturer human resource improvement program can be through various ways including through " $5 \mathrm{P}$ " as follows (1). Short course entrepreneurship program (entrepre-neurship training program for lecturers), (2) Entrepreneurship seminar / workshop / workshop program. (3) lecturer apprenticeship programs in the business world, (4) workshop programs with business partners / businesses (5) coaching / mentoring programs for new lecturers. With the " $5 \mathrm{P}$ " program, it is expected that every lecturer (not just entrepreneurship lecturer) will be able to fulfill the " $5 \mathrm{M}$ " above.

\section{Collaboration with the Business World and Financial Institutions}

In addition to forming an entrepreneurial directorate, the Chancellor also formed a cooperation directorate led by Ms. Nurhaeni Sikki to build cooperation with the business world and financial institutions. The objectives are: 1. Improving the quality of lecturer and student human resources, 2. Opening business internship opportunities for lecturers and students, 3. Opening business cooperation opportunities especially for students / alumni. With this collaboration program it is expected that students will primarily be able to analyze and observe real forms of business so they have an idea when they become entrepreneurs.

\section{Implementation of Communipreneur}

The term Communipreneur consists of two concepts; the first is communication and the second is entrepreneurship. This concept is a development of entrepreneurship.

Communication in English is called communication sourced from Latin communicatio. The root of the word is communis which means "to make togetherness or build togetherness between two or more people".

According to Carl Iver Hovland, communication is channeling ideas or intentions from one source to another with the aim of changing the behavior of the recipient of the idea. The Big Indonesian Dictionary (KBBI) defines communication as "sending and receiving messages or news between two or more people so that the intended message can be understood".

Communication is not limited to verbal delivery, but can also be through art, symbols, emotions emanating from someone. The important thing in communication is the creation of intense encounters or meetings, both interpersonal as well as groups or individuals and groups. This becomes important so that individuals and groups will increasingly understand, recognize, and understand intentions, and find the purpose of the communication carried out.

Whereas Entrepreneurship in Indonesian is translated as entrepreneurship or entrepreneurship, which has the meaning of a process of identifying, developing and bringing vision into life. The vision can be in the form of innovative ideas, opportunities, better ways of doing things. The final result of the process is the creation of new businesses formed under conditions of risk or uncertainty.

Entrepreneurship has various meanings and experts define it according to its emphasis and emphasis. Richard Cantilion (1775) for example defines entrepreneurship as self-employment. As for Penrose (1963) states that entrepreneurial activities include the identification of opportunities in the economic system. Meanwhile, according to Harvey Leibenstein (1979) entrepreneurship includes activities needed to create or implement a company when all markets are not yet formed or clearly not identified, or the components of their production 
functions are unknown.

It's good to hear opinions from practitioners as a reflection of their experiences in their business. First, Altimese Nichole, founder of the NicholeNicole shares, said that many were eager to become entrepreneurs but became discouraged when reality struck. Entrepreneurship means staying committed to your goals beyond your good feelings. Stay on track and remember your "why".

Second, NeuroFlow's Founder and CEO stated, "Entrepreneurship means being someone who wants to jump, working hard enough to sacrifice everything around you, all in the name of solving problems because no one else is capable or has the desire."

Third, according to Jolijt Tamanaha, Director of Marketing and Finance of Fresh Prints, he stated "Entrepreneurs make their way to the endless list of problems with grit, passion, and energy. Even though it's intense, being an entrepreneur means you can live your life learning in extraordinary amounts and maximizing your impact on the world because you have to overcome the most difficult problems.

Fourth, Nicole Faith, Founder of 10 Carat Creation, he explained, "Being an entrepreneur means having a plan and vision but still succeeding or trying to succeed when the plan is a mess and you only have a vision. It also means knowing when to give up, especially if your idea doesn't work because of a force outside yourself.

Fifth, Mike Kim, co-founder and COO of KPOP Foods, He stated that, "Entrepreneurship is not for the faint of heart. I am a veteran of the US Army. I have been at war and I have experienced many difficult situations. However, I can honestly say that starting a company is just as difficult, even though in a different way. Even though no life may be in danger, the battles you face on your entrepreneurial journey can last for years without a break. Creating a successful business requires a large amount of action, perseverance, and confidence. If you understand this and choose to continue, you will find a rich experience of gifts.

Meanwhile, to embody the vision and mission of the University, FISIP USB through the Department of Communication Science explores the concept of Communipreneuras the developmentorincorporation of the concept of entrepreneurship. According to the Chairperson of the Department of Communication Studies, Pupi Indriati Zaelani, communicators aim to educate and train students and students or the general public to become reliable entrepreneurs in various types of businesses by utilizing information and communication technology. Through this concept, it is hoped that young entrepreneurs in the field of communication will be born, meaning that with their expertise in the field of communication they will be able to live independently and not rely on increasingly difficult work opportunities.

At this time the Start Up in the field of communication or startups made by entrepreneurs from Indonesia is again being looked at by foreign investors. Many Star Ups have been born to young people both as YouTuber, Influenzer, News Anchor, Photographer, Scrif Wraiter etc.

The concept of communicator is made to direct students or high school students / equivalent so that they are motivated to follow in the footsteps of their seniors who have successfully built independence through the field of communication. In the initial stage, there were four fields introduced to beginners, namely the field of Photography which was fronted by a certified professional photographer, Tanto Trisno, the video field fronted by professional Daniel Matulesy, Public Speaking which was taken care of by the famous News Anchor from Inews TV, Tresia Wulandari and Scrift Wraiting which is led by Reza Saiful Rahman.

The first field is photography. According to Tanto, almost all millennials today have cameras integrated with mobile phones. With a variety of lens sizes but it has been designed as easy as possible to operate it, then all millennial groups should be able to use it. But not a few people who have not used this camera to its full potential, especially for business or business. In some of his training Tanto tried to introduce basic terms in photography such as the terms "shutter speed", "aperture", "ISO speed", "exposure compensation", "white balance"? etc. Tanto also introduced camera basics. With that you will get to know the camera better and understand better about how to get around the camera modes and settings to get an amazing shot. And more importantly, how the skill to use this camera can make money.

The second area of Communipreneur is Vidiography. According to the Head of the USB TV Laboratory, Daniel Matulesy, the field of communicators loved by millennials is videography. Integrated video facilities on mobile phones need to be utilized by the younger generation to express their creativity in recording various events that have news or aesthetic value. Videography is one of the material taught directly for the practice of recording a moment / event which will later be summarized into a video. In this videography training students are assigned to make videos with the company profile theme. With their creative ideas they are trained and given the responsibility to produce an interesting video. 
All training programs are packaged in a concise and structured manner so that they are easy to understand so as to be able to provide significant improvement in skills in a relatively short time to students. Video editing skills have the potential to make money.

The third area of communication that has been awaited by millennials is public speaking. There are several factors that are taught to students in order to succeed and succeed in public speaking. Such material instills self-confidence, intonation, expression, ability to blend and melt the atmosphere, and look into the audience. In addition to conveying theories of public speaking, Tresia also occasionally conveyed her personal experience as a Anchor news on several private television.

And the fourth field is Script Wraiting. According to Reza Saiful Rahman, currently many social media users have cool gadgets and editing tools to create posts that attract lots of followers. Cool captions can also make them want to know more about caption makers. According to Kang Reza there are four tips that can be followed to increase followers with the power of words.

First, Create a personality and stick to it! Caption provides an opportunity to express personality by building different 'voices' on social media. Are you an easy going, exciting, and want to build a cheerful approach on social media? Don't be too formal when writing posts, use slang, relaxed and simple phrases, with a touch of humor. If you want to build a professional persona, use complete and descriptive sentences to convey your message. Even so, don't ever try to be someone else. The key is to be yourself and build your personality when writing content so that you can reflect who you are.

Second, make a simple caption. Followers won't have much time to read a long paragraph. For this reason, make sure the maximum caption length is three lines (100-150 characters). If you want to write a long caption, start with interesting sentences that make the audience curious and want to read on. One way to attract people's attention is to use alliteration or sound repetition in a phrase: "sin, sand, and swimming!" or "ice cream on my mind."

Third, make simple questions. One of the important things to build our presence on social media is engagement, or interaction with followers, as a way to add likes and comments, and increase their interest in our account. Use simple questions in the caption related to our post so they are provoked to respond like: "What do you prefer?" or "what is your favorite?" This will give them involvement.
Fourth, not too many \#Hashtags. There is a misunderstanding that occurs in social media users where they think that many hashtags will cause a lot of views and followers. Use a maximum of three hashtags and make sure they are relevant and reflect the post.

\section{CONCLUSIONS}

Sangga Buana University as a campus that claims to be an entrepreneurial campus is required to continue to design various policies to support the birth of independent and entrepreneurial students.

Communication Study Program at the Faculty of Social and Political Sciences (FISIP) USB is demanded to develop innovation and implement the concept of communicators through four fields, namely photography, videography, public speaking and script writers.

One thing that distinguishes it from other campuses, Sangga Buana University has applied the holisticpreneur concept in which all academicians are directed not only to pursue material aspects in business but also to prioritize social aspects so as to create a balance between the world and the hereafter.

\section{REFERENCES}

Dinis Valentino, MM, MBA (2018), Entrepreneurship Seminar Material entitled "Ten Commandement to Create Your Own Business", Delivered on BSI campuses,

https://ristekdikti.go.id/kolom-opini/strategi-perguruantinggi-membifest-entrepreneurial-campus/

Iswanaji, Chaidir (2009), Tantangan Mengembangkan Entrepreneurship di PTS Khususnya Universitas Tidar Magelang, Majalah Ilmiah Dinamika, 32(2)

Kuswara Heri \& Wijaya A Johanes (2017), "BeYoung (read: mother) Success this second!", Publisher: Andi.

Kuswara Heri (2011). Success Strategies to Become Young Entrepreneurs. BSI Campus Entrepreneur Magazine, viz, 4(2).

Kuswara Heri (2016. Creating an Entrepreneurial Campus is a Must, available on the site: www.dikti.go.id

Kuswara Heri (2019), What are you doing in college if you can't succeed, 9 smart moves to achieve a brilliant career, Publisher: Kaifa.

Pujiriyanto (2013). The Analysis of Entrepreneurship Education Profile for Educational Institutions of Hihger Education in Yogjakarta. Jurnal Dewantara, $1(1)$.

Warasasmita Yuyun, MSc. (2018). The Role of Alumni and Universities in Developing an Entrepreneurial Soul in All Sectors Towards. Entrepreneurial Economy available http: //www.universitasborobudur. ac.id/ index.php/article/109-seri-kewirausaha.html. 